\title{
GEOCHEMICAL CONSIDERATIONS UPON THE BANATITES FROM BUDUREASA-PIETROASA AREA (APUSENI MOUNTAINS, ROMANIA)
}

\author{
CORINA IONESCU ${ }^{1}$, NICOLAE HAR ${ }^{1}$
}

\begin{abstract}
Various methods (T.A.S., Irvine and Baragar, Maniar and Piccoli, and Pearce diagrams) were used for the characterization of the Budureasa-Pietroasa banatites. The global geochemical characteristics of the rocks are in good agreement with the general features of the banatites, however showing some peculiar differences.
\end{abstract}

Key words: Laramian magmatism. Banatites. Granodiorites. Rhyolites. Basalts. Lamprophyres. Chemical features. Tectonic discrimination.

\section{INTRODUCTION}

Budureasa (North) and Pietroasa (South) (Fig. 1) represent large intrusive bodies, mainly granodioritic, associated to the huge pluton from Bihor Massif, Apuseni Mountains (Stoicovici and Sălăgean, 1970; Borcoş and Andrei, 1988 - in Borcoş and Vlad, 1994). They belong to the second stage of the Laramian magmatism (Ştefan et al., 1988 and 1992). Several dacite, rhyolite and rhyodacite dykes, striking NW-SE, are crossing the two bodies (Fig. 2 and 3). The final magmatic stage generated later several basic dykes (basalts, lamprophyres).

Ştefan et al. (1992) have studied the petrochemical and geochemical features of the banatites from the Northern Apuseni Mountains and concluded upon the complex evolution of the $\mathrm{I}^{\text {st }}$ and $\mathrm{II}^{\text {nd }}$ stages of calcalkaline magmas connected with an ocean crust subduction. According to the cited authors, the differentiating processes took place in intermediate magmatic chambers, simultaneously with the variable assimilation of the country rocks.

In order to characterize the Budureasa and Pietroasa banatites chemistry, several chemical analyses were performed: 25 on granodiorites ( 9 from Budureasa and 16 from Pietroasa; table 1), 10 on rhyolites (4 from Budureasa and 6 from Pietroasa; table 2) and 6 on basic rocks (Pietroasa; table 3). They were petrochemically interpreted, focussing on the following:

- the chemical character (Irvine and Baragar, 1971 and Maniar and Piccoli, 1989);

1 Babeş-Bolyai University of Cluj-Napoca, Mineralogy Department, 1 Kogălniceanu Str, 3400 Cluj-Napoca, Romania. E-mail: corinai@bioge.ubbcluj.ro 
- the banatite genesis, related to collision or subduction time (De La Roche diagram, acc. to Batchelor and Bowden, 1985);

- the tectonic settings of the banatites (Maniar and Piccoli, 1989 and Pearce et al., 1984).

Fig. 1. The location of the Laramian granodiorite intrusions (a) from Budureasa and Pietroasa, in the Apuseni Mountains, Romania

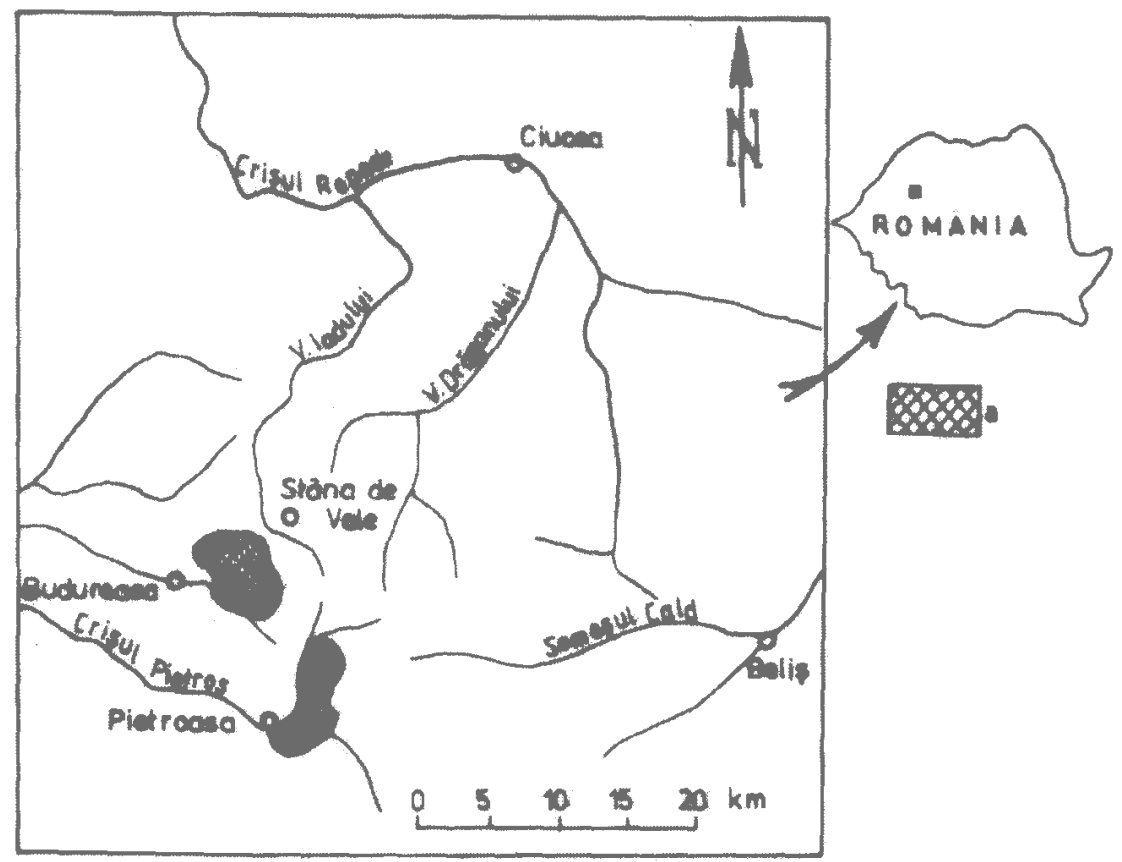

The petrogeochemical investigation provided interesting conclusions concerning the tectono-magmatic emplacement environments of the Budureasa and Pietroasa igneous bodies, but the conclusions have to be considered with some precautions due to the small number of analyses, their relatively limited spatial distribution, as well as the insufficience of agedating.

Analytical data (tables 1,2 and 3) show the variation of $\mathrm{SiO}_{2}$ from $41.80 \%$ to $75 \%$. The $\mathrm{Na}_{2} \mathrm{O}$ content is lower $(2.80-4.48 \%$ for the granodiorites, $0.69-3.07 \%$ for the rhyolites and 2.64-4.00 for the basic rocks) than the amount considered normal by Giuscă et al. (1966).

The igneous rocks of the Budureasa and Pietroasa bodies belong mostly to the granodioritic-granitic magmas and only subordinately to the dioritic and gabbroic ones. 


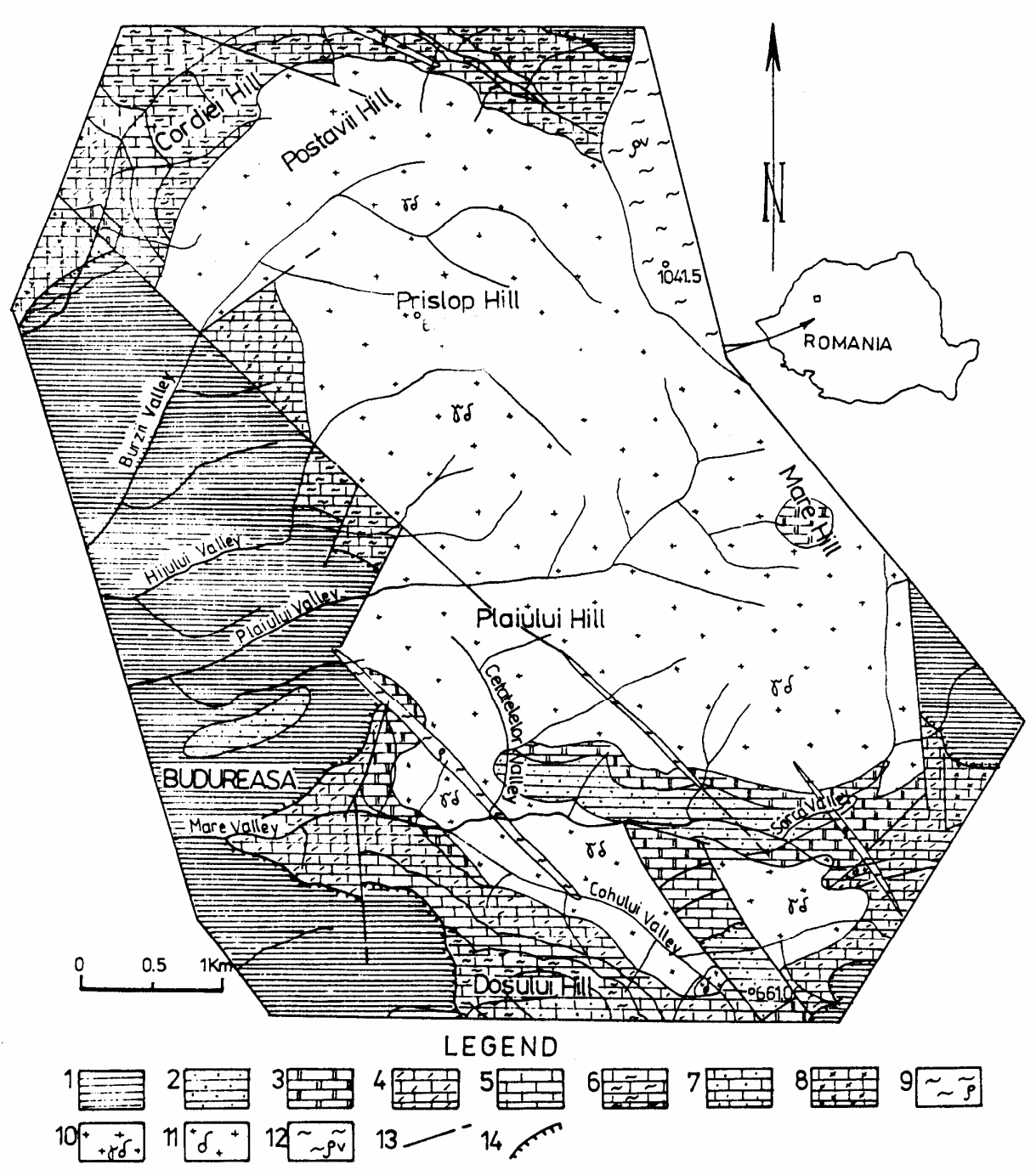

Fig. 2. The geological sketch of the Budureasa area (according to Popa et al., 1984; lonescu, 1997). Unpubl. data. Legend: Arieşeni Nappe: 1 - Permian-Scithian (siliciclastic rocks); Ferice Nappe: 2- Scithian (siliciclastic rocks); 3 - Anisian (dolostones and dolomitic limestones); 4 - Ladinian (limestones); 5 - CarnianNprian (limestones); 6 - Rhaetian (limestones); 7 - Lower Jurassic (limestones); 8 - Cretaceous (calci-siliciclastic rocks). Laramian (Banatitic) magmatism: 9 - Rhyolites-rhyodacites; 10 - Granodiorites; 11 - Diorites; 12 - Vlădeasa rhyolites. 13 - Fault; 14 - Overthrust line. 


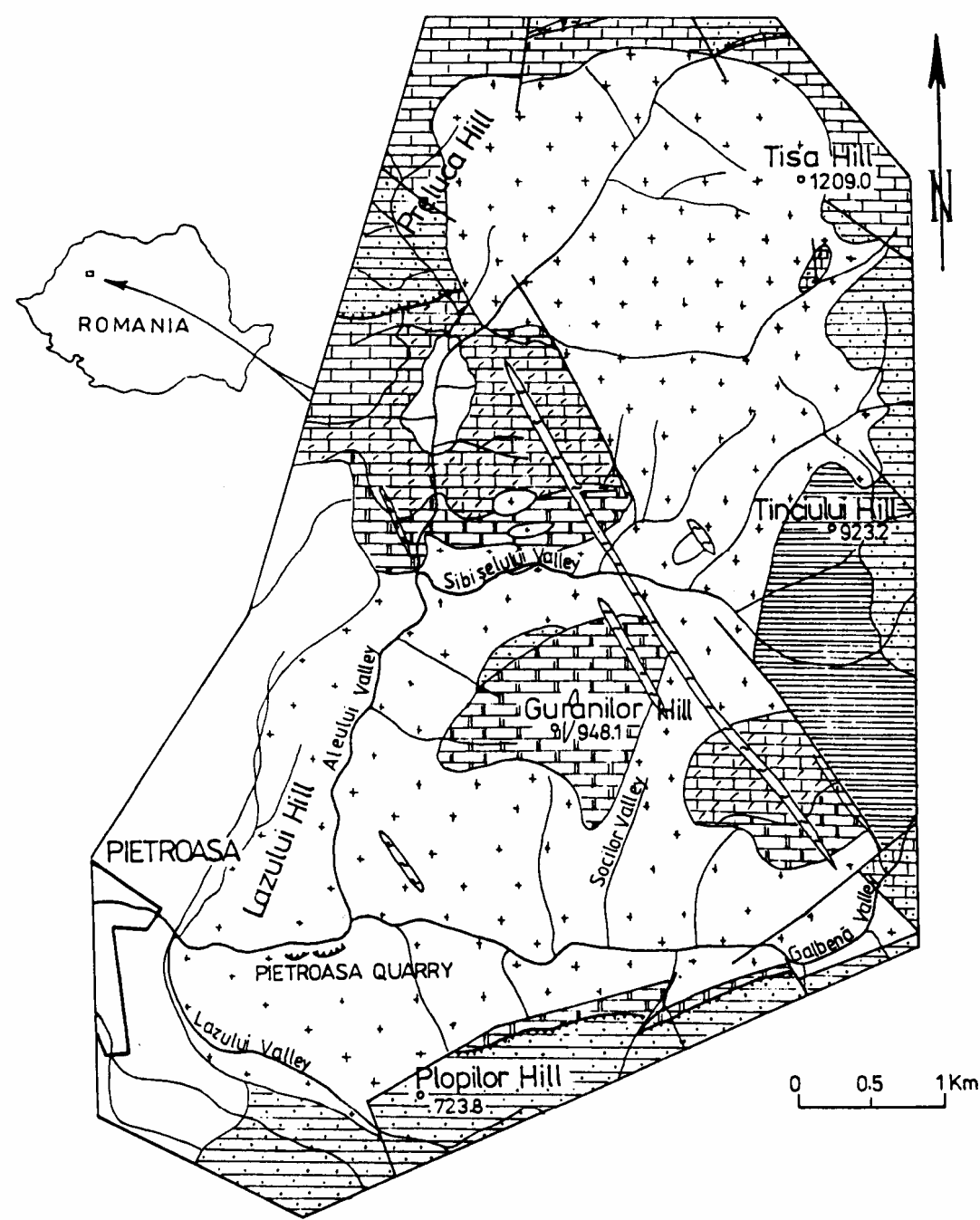

LEGEND

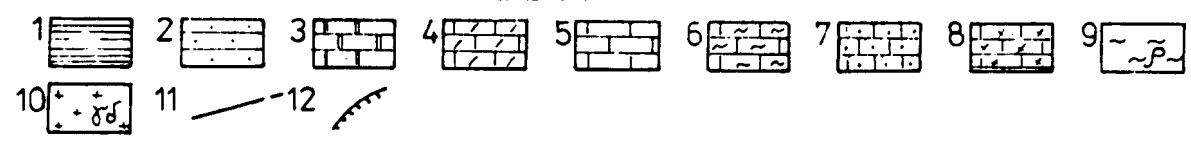

Fig. 3. The geological sketch of the Pietroasa area (according to Popa et al., 1990; lonescu, 1997). Unpubl. data. Legend: Arieşeni Nappe: 1 - Permian-Scithian (siliciclastic rocks); Ferice Nappe: 2- Scithian (siliciclasti rocks); 3 - Anisian (dolostones and dolomitic limestones); 4 - Ladinian (limestones); 5 - CarnianNorian (limestones); 6 - Rhaetian (limestones); 7 - Cretacic (calci-siliciclastic rocks); 8 - Quaternary. Laramian (Banatitic) magmatism: 9 - Rhyolitesrhyodacites; 10 - Granodiorites; 11 - Fault; 12 - Overthrust line. 
GEOCHEMICAL CONSIDERATIONS UPON THE BANATITES FROM BUDUREASA-PIETROASA AREA

Table 1.

The chemical analyses of the granodiorites from Budureasa and Pietroasa.

\begin{tabular}{|c|c|c|c|c|c|c|c|c|c|c|c|c|}
\hline & \multicolumn{12}{|c|}{ Chemic al composition(\%) } \\
\hline & $\mathrm{SiO}_{2}$ & $\mathrm{Al}_{2} \mathrm{O}_{3}$ & $\mathrm{Fe}_{2} \mathrm{O}_{3}$ & $\mathrm{FeO}$ & $\mathrm{CaO}$ & $\mathrm{MgO}$ & $\mathrm{K}_{2} \mathrm{O}$ & $\mathrm{Na}_{2} \mathrm{O}$ & $\mathrm{TiO}_{2}$ & $\mathrm{P}_{2} \mathrm{O}_{5}$ & $\mathrm{MnO}$ & $\mathrm{H}_{2} \mathrm{O}$ \\
\hline \multicolumn{13}{|c|}{ BUDUREASA ${ }^{*}$} \\
\hline 607 & 70.83 & 14.79 & 2.55 & 0.00 & 2.73 & 0.85 & 3.00 & 3.64 & 0.24 & 0.41 & 0.59 & 0.37 \\
\hline 608 & 72.10 & 13.82 & 1.91 & 0.00 & 2.31 & 1.12 & 2.84 & 3.60 & 0.24 & 1.74 & 0.36 & 0.06 \\
\hline 610 & 70.69 & 14.60 & 2.76 & 0.00 & 2.13 & 1.37 & 2.92 & 3.08 & 0.38 & 1.05 & 0.57 & 0.45 \\
\hline 614 & 69.80 & 14.51 & 2.68 & 0.00 & 2.87 & 1.30 & 3.08 & 3.04 & 0.32 & 1.78 & 0.69 & 0.08 \\
\hline 619 & 69.31 & 14.01 & 2.70 & 0.00 & 2.75 & 1.70 & 3.40 & 2.80 & 0.46 & 0.60 & 0.58 & 1.69 \\
\hline 620 & 69.60 & 14.61 & 2.90 & 0.00 & 2.42 & 1.50 & 3.20 & 3.20 & 0.46 & 0.66 & 0.59 & 0.86 \\
\hline 621 & 69.04 & 14.54 & 2.80 & 0.00 & 2.61 & 1.30 & 3.30 & 2.90 & 0.52 & 0.58 & 0.85 & 1.56 \\
\hline 625 & 70.06 & 14.37 & 2.55 & 0.00 & 2.08 & 1.70 & 3.80 & 2.80 & 0.52 & 0.04 & 0.41 & 1.70 \\
\hline 626 & 69.84 & 14.93 & 2.80 & 0.00 & 2.33 & 1.50 & 3.00 & 3.50 & 0.52 & 0.18 & 0.46 & 0.94 \\
\hline \multicolumn{13}{|c|}{ PIETROASA ${ }^{* *}$} \\
\hline 80 & 66.13 & 12.00 & 4.20 & 1.81 & 3.40 & 3.20 & 2.79 & 3.93 & 0.75 & 0.16 & 0.09 & 1.01 \\
\hline 81 & 66.82 & 12.35 & 3.57 & 1.67 & 3.08 & 2.80 & 2.72 & 3.31 & 0.75 & 0.16 & 0.09 & 1.71 \\
\hline 89 & 67.53 & 13.06 & 3.43 & 1.81 & 2.46 & 2.30 & 3.39 & 4.25 & 0.80 & 0.16 & 0.10 & 0.25 \\
\hline 136 & 67.83 & 11.42 & 3.18 & 1.67 & 3.01 & 2.40 & 3.88 & 4.12 & 0.90 & 0.16 & 0.11 & 0.80 \\
\hline 208 & 66.35 & 13.22 & 3.81 & 1.81 & 3.40 & 2.40 & 3.49 & 3.31 & 0.75 & 0.16 & 0.09 & 0.71 \\
\hline 209 & 66.86 & 12.54 & 3.73 & 1.54 & 2.41 & 2.30 & 3.66 & 3.69 & 0.80 & 0.15 & 0.08 & 1.22 \\
\hline 221 & 67.07 & 13.04 & 3.42 & 1.81 & 2.71 & 2.40 & 3.56 & 3.69 & 0.65 & 0.14 & 0.07 & 0.94 \\
\hline 233 & 66.25 & 12.14 & 3.73 & 2.23 & 3.18 & 3.00 & 3.32 & 3.82 & 0.85 & 0.20 & 0.08 & 1.00 \\
\hline 260 & 66.33 & 12.52 & 3.65 & 1.95 & 2.76 & 3.10 & 3.37 & 3.93 & 0.85 & 0.20 & 0.09 & 0.86 \\
\hline 265 & 67.37 & 11.34 & 3.57 & 1.67 & 3.37 & 2.50 & 3.54 & 3.93 & 0.75 & 0.16 & 0.08 & 0.70 \\
\hline 274 & 67.45 & 11.82 & 3.72 & 2.09 & 2.67 & 2.60 & 3.61 & 4.58 & 0.75 & 0.18 & 0.09 & 0.31 \\
\hline 503 & 63.53 & 11.90 & 3.65 & 1.95 & 2.08 & 3.50 & 3.06 & 3.18 & 0.80 & 0.18 & 0.08 & 2.18 \\
\hline 505 & 66.76 & 12.80 & 3.65 & 1.96 & 2.44 & 2.90 & 3.18 & 3.63 & 0.80 & 0.16 & 0.07 & 0.93 \\
\hline 555 & 66.73 & 12.54 & 4.03 & 1.96 & 2.99 & 2.60 & 3.23 & 3.66 & 0.85 & 0.19 & 0.10 & 0.31 \\
\hline 556 & 65.72 & 12.47 & 4.03 & 1.96 & 2.82 & 3.30 & 3.01 & 3.93 & 0.80 & 0.20 & 0.10 & 0.35 \\
\hline 561 & 64.40 & 11.68 & 3.81 & 1.11 & 3.51 & 2.90 & 3.90 & 3.63 & 0.80 & 0.16 & 0.09 & 0.35 \\
\hline
\end{tabular}

* Analyst: G. Nedelcu - I.P.G.G. Bucureşti. 1983-1986

** Analyst: C. Agrigoroaie - I.P.G.G. Bucureşti. 1988

***The location of the samples: BUDUREASA: 607 - Gallery 8; 608 - Gallery 8; 610 Gallery 8; 614 - Gallery 6 bis.; 619 - Lateral drift no. 350/Gallery 6 bis; 620 - Gallery 6 bis; 621 - Lateral drift no.250/Gallery 6 bis; 625 - Lateral drift no. 350/ Gallery 8; 626 Gallery 8; PIETROASA: 80 - Sebisel Valley; 81 - Sebisel Valley; 89 - Sebisel Valley; 136 - Gallery 3; 208 - Gallery 3; 209 - Gallery 3; 221 - Gallery 3; 233 - Gallery 3; 260 - Gallery 3; 265 - Gallery 3; 274 - Gallery 3; 503 - Aleu Valley; 505 - Aleu Valley; 555 - Prislop Hill; 556 - Prislop Hill; 560 - Aleu Valley; 561 - Aleu Valley. 
Table 2.

The chemical analyses of the rhyolites from Budureasa and Pietroasa.

\begin{tabular}{|c|c|c|c|c|c|c|c|c|c|c|c|c|}
\hline \multirow{2}{*}{\begin{tabular}{|l} 
Probe \\
no.***
\end{tabular}} & \multicolumn{12}{|c|}{ Chemical } \\
\hline & $\mathrm{SiO}_{2}$ & $\mathrm{Al}_{2} \mathrm{O}_{3}$ & $\mathrm{Fe}_{2} \mathrm{O}_{3}$ & $\mathrm{FeO}$ & $\mathrm{CaO}$ & $\mathrm{MgO}$ & $\mathrm{K}_{2} \mathrm{O}$ & $\mathrm{Na}_{2} \mathrm{O}$ & $\overline{\mathrm{TiO}_{2}}$ & $\mathrm{P}_{2} \mathrm{O}_{5}$ & $\mathrm{MnO}$ & $\mathrm{H}_{2} \mathrm{O}$ \\
\hline \multicolumn{13}{|c|}{ BUDUREASA $^{*}$} \\
\hline 588 & 74.83 & 7.80 & 1.16 & 0.72 & 1.50 & 1.16 & 5.78 & 2.43 & 0.15 & 0.08 & 0.05 & 0.40 \\
\hline 590 & 75.00 & 8.72 & 1.14 & 0.80 & 1.38 & 0.98 & 3.85 & 1.71 & 0.11 & 0.08 & 0.04 & 0.48 \\
\hline 592 & 74.17 & 7.80 & 0.99 & 1.09 & 1.86 & 1.18 & 4.18 & 1.40 & 0.15 & 0.11 & 0.02 & 2.77 \\
\hline 593 & 73.26 & 7.20 & 0.85 & 1.22 & 1.62 & 1.10 & 5.38 & 1.69 & 0.38 & 0.08 & 0.04 & 1.76 \\
\hline \multicolumn{13}{|c|}{ PIETROASA $^{\star *}$} \\
\hline 25 & 67.31 & 8.36 & 1.48 & 1.80 & 2.52 & 1.70 & 4.10 & 2.70 & 0.30 & 0.14 & 0.06 & 0.42 \\
\hline 26 & 67.52 & 8.37 & 1.52 & 1.84 & 2.40 & 1.21 & 3.93 & 2.74 & 0.28 & 0.14 & 0.07 & 0.52 \\
\hline 52 & 67.96 & 8.28 & 1.63 & 1.67 & 2.34 & 1.74 & 3.77 & 2.92 & 0.22 & 0.15 & 0.06 & 0.79 \\
\hline 87 & 68.10 & 9.53 & 1.40 & 1.80 & 3.00 & 1.58 & 4.34 & 3.07 & 0.29 & 0.18 & 0.07 & 0.69 \\
\hline 218 & 71.46 & 10.06 & 1.02 & 1.32 & 1.56 & 1.35 & 4.58 & 1.75 & 0.20 & 0.12 & 0.04 & 2.58 \\
\hline 517 & 72.50 & 8.56 & 0.98 & 0.92 & 3.00 & 1.13 & 2.89 & 0.69 & 0.15 & 0.13 & 0.04 & 2.58 \\
\hline
\end{tabular}

* Analyst: G. Nedelcu - I.P.G.G. Bucureşti. 1983

** Analyst: G. Nedelcu - I.P.G.G. Bucureşti. 1986

***The location of the samples: BUDUREASA: 588 - Drilling 2/Gallery 6; 590 - Drilling 2/Gallery 6; 592 - Gallery 8; 593 - Gallery 8; PIETROASA: 25 - Gallery 3; 26 - Gallery 3; 52 - Gallery 3; 87 - Sebisel Valley; 218 - Gallery 3; 517 - Aleu Valley.

Table 3.

The recalculated chemical analyses* of the basic rocks from Pietroasa.

\begin{tabular}{|c|c|c|c|c|c|c|c|c|c|c|c|}
\hline $\begin{array}{c}\text { Probe } \\
\text { no. }\end{array}$ & \multicolumn{10}{|c|}{ Ch e m i c a l co m p o s i t o n $(\%)$} \\
\hline & $\mathrm{SiO}_{2}$ & $\mathrm{Al}_{2} \mathrm{O}_{3}$ & $\mathrm{Fe}_{2} \mathrm{O}_{3}$ & $\mathrm{FeO}$ & $\mathrm{CaO}$ & $\mathrm{MgO}$ & $\mathrm{K}_{2} \mathrm{O}$ & $\mathrm{Na}_{2} \mathrm{O}$ & $\mathrm{TiO}_{2}$ & $\mathrm{P}_{2} \mathrm{O}_{5}$ & $\mathrm{MnO}$ \\
\hline $22^{*}$ & 47,66 & 17,76 & 13,31 & 0,00 & 4,19 & 5,39 & 1,2 & 4,24 & 3,96 & 1,51 & 0,39 \\
\hline 110 & 47,60 & 16,66 & 12,90 & 0,00 & 4,97 & 7,31 & 1,87 & 4,06 & 3,21 & 1,02 & 0,24 \\
\hline 115 & 48,99 & 16,85 & 15,17 & 0,00 & 3,62 & 6,09 & 0,65 & 3,17 & 3,32 & 1,17 & 0,39 \\
\hline 118 & 44,13 & 21,67 & 13,55 & 0,00 & 1,97 & 9,30 & 0,31 & 2,76 & 3,93 & 1,55 & 0,17 \\
\hline 144 & 47,35 & 18,51 & 13,08 & 0,00 & 2,49 & 7,85 & 2,50 & 3,81 & 2,46 & 1,49 & 0,31 \\
\hline 336 & 42,85 & 17,26 & 13,93 & 0,00 & 2,97 & 7,31 & 1,03 & 4,57 & 2,65 & 2,03 & 0,33 \\
\hline Average & 46,43 & 18,12 & 13,66 & 0,00 & 3,67 & 7,21 & 1,26 & 3,77 & 3,26 & 1,46 & 0,31 \\
\hline
\end{tabular}

**Analyst: G. Nedelcu - I.P.G.G. Bucuresti. 1983

Fitting well to the features of the Laramian igneous province, the Budureasa and Pietroasa intrusions apparently suggest a magmatic evolution from acidic terms towards two major directions: one peracidic, represented by rhyolites, and the other basic, represented by diorites and gabbros. This evolution is similar to the subalkaline differentiation line (Giuşcă et al., 1966). The exceptions indicate only some accidental aspects of the differentiation process, because the contamination with the country rocks did not produced essential changes of the magma chemistry. 


\section{GRANODIORITES}

The main mass of the intrusive bodies of Budureasa and Pietroasa has a general granodioritic character, despite their marginal unhomogeneity (due to the frequency of xenoliths, acc. to Mârza and lonescu, 1998) and the local variations to monzodioritic, quartz-monzodioritic or granitic features (Erhan, 1980; Istrate and Udubaşa, 1980; Ştefan et al., 1992; Marincea, 1993).

The granodiorites (Plate I, Fig. 1) are constituted of quartz, plagioclase feldspars (oligoclase mainly), potassic feldspars, biotite, seldom hornblende. The texture is grainy, hipidiomorphyc one. Often porphyritic textures, mainly as marginal facies, occur.

The granodiorite chemical data are given in the table 1. The granodiorites acidity varies between $63.53 \%$ and $70.83 \% \mathrm{SiO}_{2}$. The $\mathrm{Na}_{2} \mathrm{O}$ contents range between $2.80 \%$ and $4.58 \%$, while $\mathrm{K}_{2} \mathrm{O}$ range between 2.72 and $3.90 \%$. A quite obvious difference can be noticed between the rocks of the two areas: granodiorites from Budureasa are a little more acid and contain more $\mathrm{Al}$ and $\mathrm{Mn}$ than those of the Pietroasa body. In return, they are poorer in $\mathrm{Fe}, \mathrm{Ca}$, alkalies and $\mathrm{Ti}$.

\subsection{Irvine and Baragar diagram (1971)}

In the ternary diagram $\mathrm{MgO}-\left(\mathrm{Na}_{2} \mathrm{O}+\mathrm{K}_{2} \mathrm{O}\right)-\mathrm{FeO}$ (Fig. 4) the Budureasa and Pietroasa rocks join the calco-alkaline field, more precisely the subalkaline field (Fig. 5), confirming their setting between the general features of the banatites (Giuşcă et al., 1965). The totall separated grouping of the rocks from the two areas is to be noted. It is obvious to notice the lower-alkaline character of the Pietroasa granodiorites comparatively to the Budureasa ones.

\subsection{Maniar and Piccoli diagram (1989)}

The use of this tectonic ${ }^{2}$ discrimination diagram for granitoidic rocks ${ }^{3}$ finally allowed the tectonic setting recognition for the environment of the rocks discussed above, after the selection and elimination steps:

a) The first stage of discrimination steps is based on the $\mathrm{SiO}_{2}-\mathrm{K}_{2} \mathrm{O}$ diagram (Fig. 6), which shows that the analysed rocks do not fall into the oceanic plagiogranites group (OP).

\footnotetext{
${ }^{2}$ Granitoids are categorized by tectonic environment in:

- Orogenic granitoids: island arc granitoids (IAG), continental arc granitoids (CAG), continental collision granitoids (CCG) and post-orogenic granitoids (POG);

- Anorogenic granitoids: rift-related granitoids (RRG), continental epeirogenic uplift granitoids (CEUG) and oceanic plagiogranites (PG).

${ }^{3}$ Granitoids: alkali granite, granite, granodiorite, tonalite, trondhjemite, quartz diorite, quartz monzodiorite, quartz monzonite, quartz syenite, quartz alkali syenite.
} 


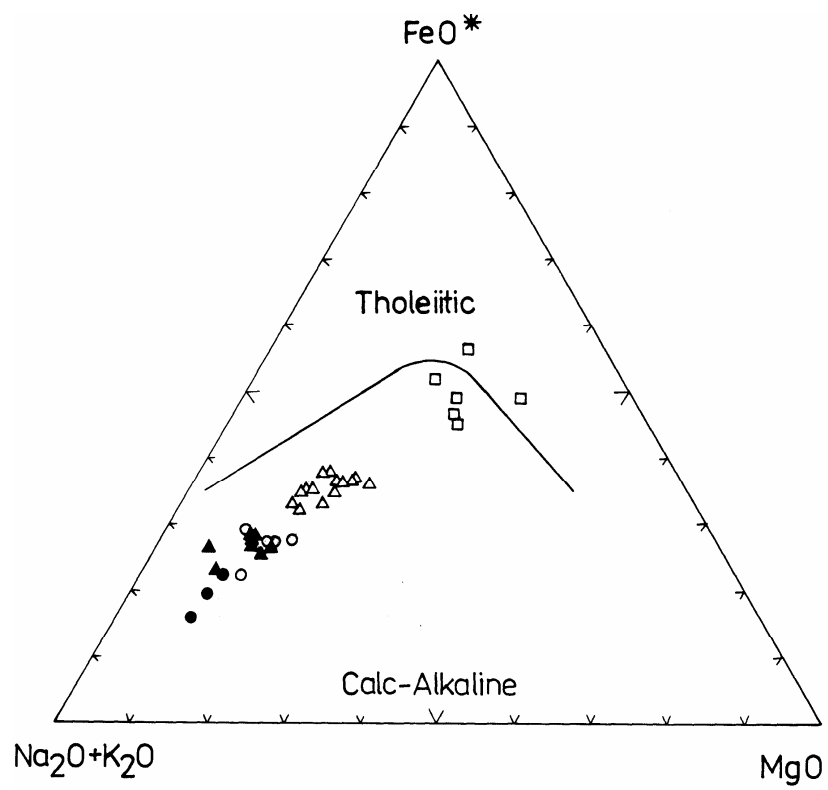

Fig. 4. The $\mathrm{MgO}-\left(\mathrm{Na}_{2} \mathrm{O}+\mathrm{K}_{2} \mathrm{O}\right)-\mathrm{FeO}$ ternary diagram (acc. to Irvine and Bargar, 1971 diagram). The calc-allaline character of the Budureasa $(\sigma)$ and Pietroasa $(\Delta)$ granodiorites, Budureasa $(\lambda)$ and Pietroasa $(\mathrm{O})$ rhyolites. The calcalkalinetholeiitic transition character of the basic rocks from Pietroasa ( $\square$ ).

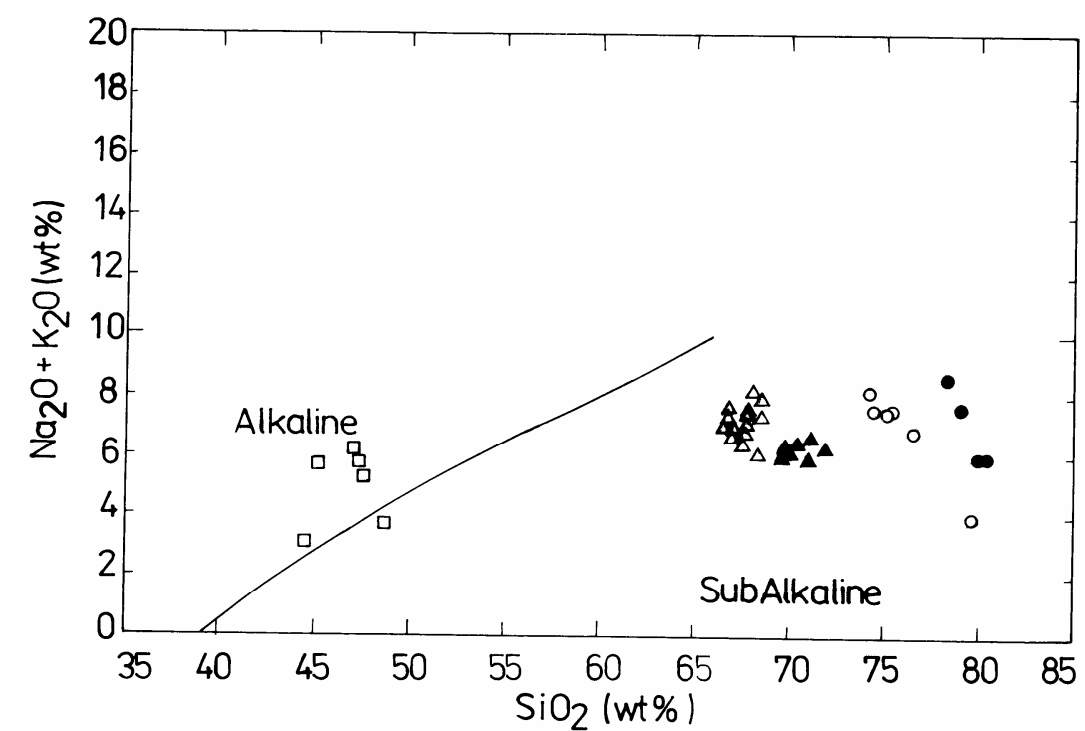

Fig. 5. The subalkaline character (acc. to Irvine and Bargar, 1971 diagram) of the Budureasa $(\sigma)$ and Pietroasa $(\Delta)$ granodiorites, Budureasa $(\lambda)$ and Pietroasa (O) rhyolites and Pietroasa basic rocks ( $\square$ ). 


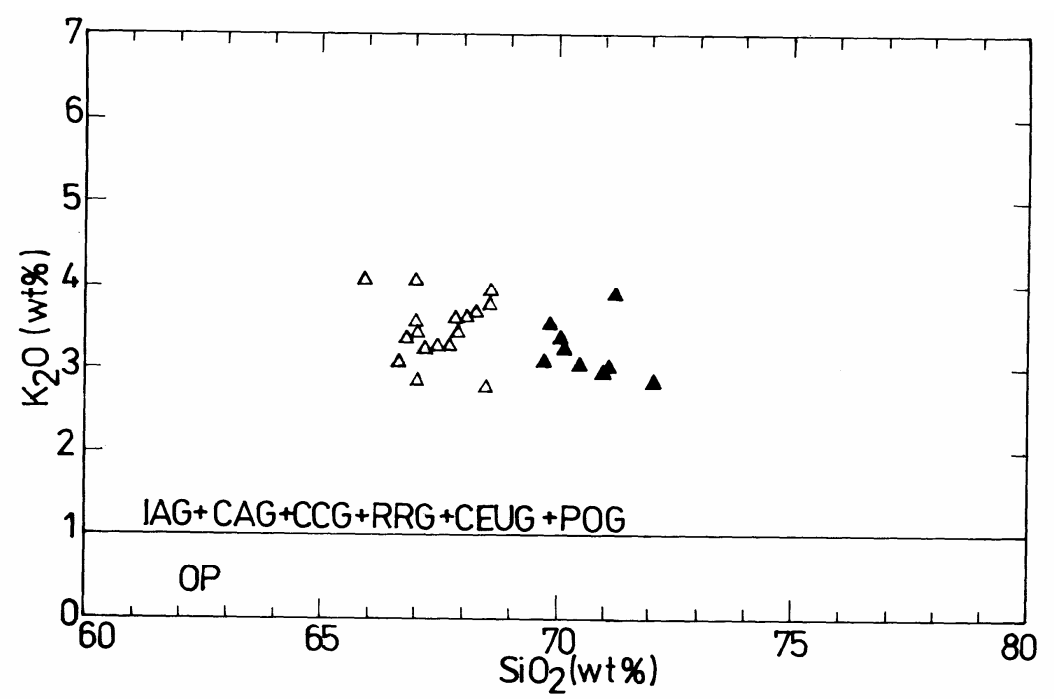

Fig. 6. The $\mathrm{SiO}_{2}-\mathrm{K}_{2} \mathrm{O}$ diagram (acc. to Maniar and Piccoli, 1989 diagram). The tectonic discrimination of the Budureasa $(\sigma)$ and Pietroasa $(\Delta)$ granodiorites.

b). On the basis of the $\mathrm{SiO}_{2}$-total $\mathrm{FeO} /$ (total $\mathrm{FeO}+\mathrm{MgO}$ ) ratio, the second tectonic discrimination step is accomplished, between the $I^{\text {st }}$ group (IAG, CAG, CCG), the II ${ }^{\text {nd }}$ group (RRG, CEUG) and the $\|^{\text {rd }}$ group (POG) (Fig. 7). The granitoids belong to the $\mathrm{I}^{\text {st }}$ group (island arc, continental arc and continental collision granitoids), also with an obvious separation between Budureasa and Pietroasa.

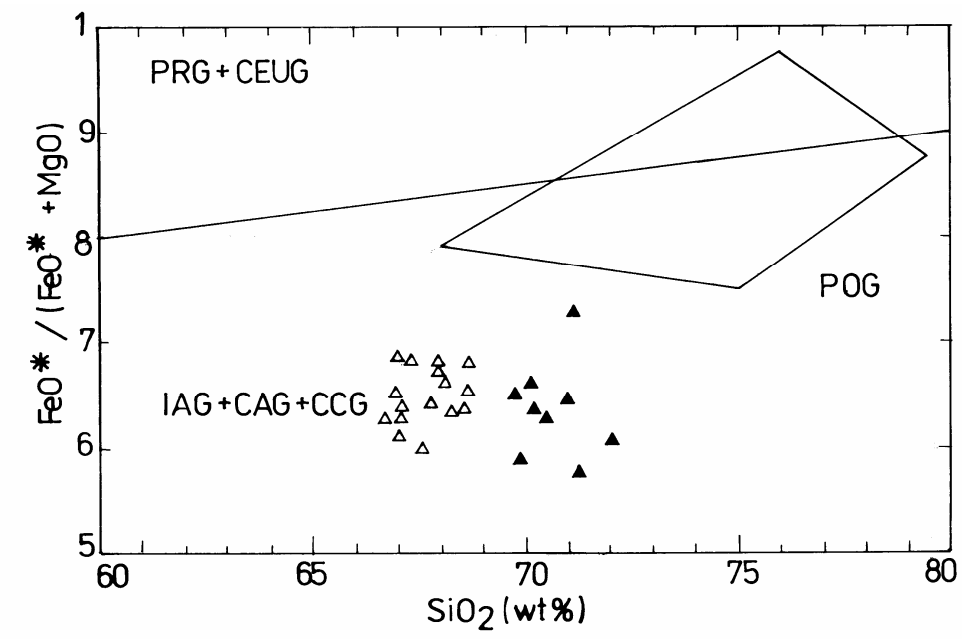

Fig. 7. The $\mathrm{SiO}_{2}$-total $\mathrm{FeO} /($ total $\mathrm{FeO}+\mathrm{MgO}$ ) diagram (acc. to Maniar and Piccoli, 1989 diagram). The second phase of the tectonic discrimination for the Budureasa $(\sigma)$ and Pietroasa $(\Delta)$ granodiorites. 
c) The third step consists in discrimination within $1^{\text {st }}$ group (IAG, CAG, CCG), using Shand's diagram in this purpose (Fig. 8). Based on the molar ratios $\mathrm{Al}_{2} \mathrm{O}_{3} /\left(\mathrm{CaO}+\mathrm{Na}_{2} \mathrm{O}+\mathrm{K}_{2} \mathrm{O}\right)-\mathrm{Al}_{2} \mathrm{O}_{3}(\mathrm{~A} / \mathrm{CNK})^{4}$ (table 4), the diagram points out the differences between the granodiorites from the two bodies: a peraluminous tendency for the Budureasa granodiorites and a peralkaline tendency for the Pietroasa ones.

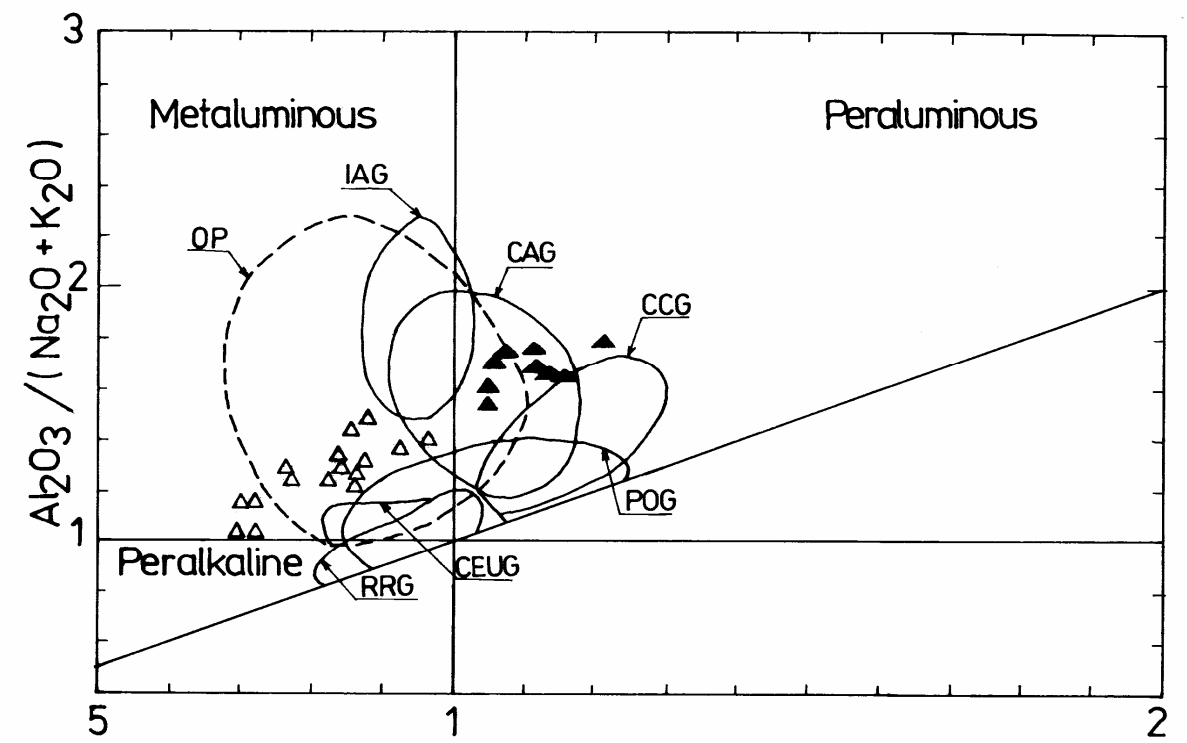

Fig. 8. The Shand's diagram (acc. to Maniar and Piccoli, 1989 diagram) for the Budureasa $(\sigma)$ and Pietroasa $(\Delta)$ granodiorites. The third phase of the tectonic discrimination.

The Budureasa rocks clearly fall in the CAG category, within the continental arc type granitoids, with the molar ratio A/CNK less than 1.15. Because of their weak peralkaline tendency, the Pietroasa granodiorites join towards the IAG+CAG common zone (that cannot be discriminated), with a trend from CAG type due to their metaaluminous character. According to this tectonic discrimination diagram, both bodies belong to the continental arc granitoids (CAG) type.

This classification is also confirmed by computing some ratios (table 4) for the use on Shand's diagram (according to Maniar and Piccoli, 1989). The Budureasa granodiorites reveal also the continental arc granitoides (CAG) characteristics.

\footnotetext{
${ }^{4}$ CCG do not have A/CNK values less than 1.05, whereas IAG+CAG, do not have A/CNK values greater than 1.15 . If the $A / C N K$ ratio is between 1.05 and 1.15 , it is not possible to discriminate between $C C G$ and IAG+CAG. Furthermore, it is not possible to discriminate between IAG and CA, using this method.
} 
The ratios used in Shand's diagram (acc. to Irvine \& Baragar, 1971) for Budureasa and Pietroasa rocks.

\begin{tabular}{|c|c|c|c|c|c|}
\hline \multicolumn{6}{|c|}{ Ratios (Multicationic parameters) } \\
\hline Probe no. & $\mathrm{Na}_{2} \mathrm{O} / \mathrm{CaO}(\%)$ & $\begin{array}{c}\mathrm{Na}_{2} \mathrm{O} / \mathrm{K}_{2} \mathrm{O} \\
(\%)\end{array}$ & $\mathrm{MgO} /$ Total FeO (\%) & $\mathrm{MgO} / \mathrm{MnO}(\%)$ & $\begin{array}{c}\mathrm{A} / \mathrm{CNK} \\
\text { ratio }\end{array}$ \\
\hline \multicolumn{6}{|c|}{ BUDUREASA } \\
\hline 607 & 1.33 & 1.21 & 0.33 & 1.44 & -1.79 \\
\hline 608 & 1.56 & 1.27 & 1.23 & 3.11 & -1.79 \\
\hline 610 & 1.44 & 1.30 & 0.49 & 2.40 & -1.65 \\
\hline 614 & 1.05 & 0.99 & 1.07 & 1.88 & -1.77 \\
\hline 619 & 1.02 & 0.82 & 1.02 & 2.93 & -1.84 \\
\hline 620 & 1.32 & 1.00 & 0.83 & 2.54 & -1.75 \\
\hline 621 & 1.11 & 0.88 & 0.93 & 1.53 & -1.77 \\
\hline 625 & 1.34 & 0.74 & 0.81 & 4.14 & -1.74 \\
\hline 626 & 1.50 & 1.16 & 0.83 & 3.26 & -1.74 \\
\hline \multicolumn{6}{|c|}{ PIETROASA } \\
\hline 80 & 1.15 & 1.40 & 0.53 & 35.55 & -2.35 \\
\hline 81 & 1.07 & 1.22 & 0.53 & 31.11 & -2.03 \\
\hline 89 & 1.72 & 1.25 & 0.44 & 23.00 & -2.20 \\
\hline 136 & 1.37 & 1.06 & 0.50 & 21.81 & -2.94 \\
\hline 208 & 0.97 & 0.95 & 0.43 & 26.60 & -2.18 \\
\hline 209 & 1.53 & 1.01 & 0.44 & 28.75 & -2.07 \\
\hline 221 & 1.36 & 1.03 & 0.46 & 34.28 & -2.18 \\
\hline 233 & 1.20 & 1.15 & 0.50 & 37.50 & -2.46 \\
\hline 260 & 1.42 & 1.16 & 0.56 & 34.44 & -2.31 \\
\hline 265 & 1.16 & 1.11 & 0.48 & 31.25 & -3.02 \\
\hline 274 & 1.71 & 1.27 & 0.48 & 28.88 & -2.85 \\
\hline 503 & 1.53 & 1.04 & 0.63 & 43.75 & -2.00 \\
\hline 505 & 1.49 & 1.14 & 0.51 & 41.42 & -2.05 \\
\hline 555 & 1.22 & 1.13 & 0.43 & 26.00 & -2.20 \\
\hline 556 & 1.39 & 1.31 & 0.55 & 33.00 & -2.20 \\
\hline 561 & 1.03 & 0.93 & 0.59 & 32.00 & -3.00 \\
\hline
\end{tabular}

The Pietroasa rocks, in accordance with the molar ratio A/CNK, fall in a more alkaline field. Because the all parameters denote a CAG type (continental arc granitoids), we consider that they also belong to the same major geotectonic setting, like the Budureasa ones.

2.3. De La Roche diagram (1980) (fide Batchelor and Bowden, 1985)

In order to complete the chemical processing of granodiorites the multicationic diagram (De La Roche R1-R2 diagram) was used. The diagram indicates important tectono-magmatic environments as defined by Pitcher in 1979 and 1982 (fide Batchelor and Bowden,1985). 
The Budureasa granodiorites aproximately join the basis of the field 2 (Fig. 9) (subduction - syn-collision). The Pietroasa granodiorites are differently placed, meaningly in a later period.

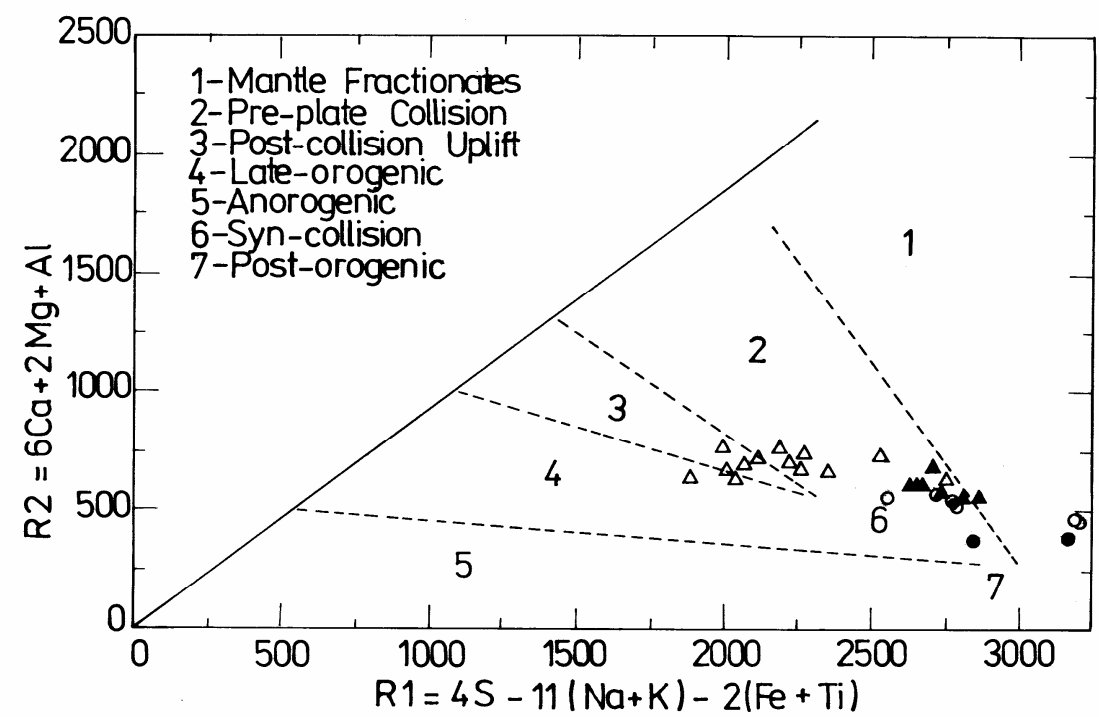

Fig. 9. The multicationic diagram of tecto-magmatic discrimination (acc. to De La Roche, 1980 diagram) for the Budureasa $(\sigma)$ and Pietroasa $(\Delta)$ granodiorites and Budureasa $(\lambda)$ and Pietroasa $(\mathrm{O})$ rhyolites.

The source tendency, reflected by the progressive, aproximately linear disposition of the samples, is marked by a general, constant, but weak increase in the $\mathrm{K}_{2} \mathrm{O}$ and $\mathrm{Na}_{2} \mathrm{O}$ contents. This indicates a slow differentiation from a common source. The so-called series trend, meaning the compositional variation normal to the source tendency, is also relatively weakly marked.

\section{RHYOLITES}

The rhyolites occur as dykes of various sizes (from tens of centimeters to tens of meters width, and from few meters up to kilometers in length) crossing both the granodiorites and the country sedimentary rocks from NNW towards SSE.

The rhyolites are constituted (Plate I, Fig. 2) of quartz and subordinately potassic feldspar and biotite phenocrysts, in a fine-grained, holocrystalline felsitic or hyalopilitic groundmass.

In order to characterize the rhyolites, 4 chemical analyses from the Budureasa, respectively 6 from the Pietroasa zones were used (table 2). The rhyolites acidity varies between $67.31 \%$ and $75 \% \mathrm{SiO}_{2}$. The $\mathrm{Na}_{2} \mathrm{O}$ content ranges from $1.40 \%$ to $3.0 \%$, while $\mathrm{K}_{2} \mathrm{O}$ from $2.89 \%$ to $5.78 \%$. The Budureasa rhyolites contain higher $\mathrm{SiO}_{2}$ than the Pietroasa ones. 
3.1. T.A.S. diagram (Le Maitre, 1984)

The T.A.S. classification diagram (Fig. 10) arranges these rocks in the $\mathrm{R}$ field (rhyolites and alkaline rhyolites). It is worth mentioning the excentricity of Budureasa samples, supersaturated in $\mathrm{SiO}_{2}$ and situated at the periphery of the domain.

Because the T.A.S. diagram shows a slight alkaline tendency, for more details the $\mathrm{SiO}_{2}-\mathrm{K}_{2} \mathrm{O}$ diagram (Fig. 11) and the peralkaline index P.I.= $\left(\mathrm{Na}_{2} \mathrm{O}+\mathrm{K}_{2} \mathrm{O}\right) / \mathrm{Al}_{2} \mathrm{O}_{3}$ (table 5) were used. With only one exception (a Budureasa alkaline rhyolite with P.I. > 1.0), the peralkaline index is less than 1.0 and all the rocks samples can be classified as rhyolites, with a weak potassic character.

\subsection{Irvine and Baragar diagram (1971)}

$\mathrm{MgO}-\left(\mathrm{Na}_{2} \mathrm{O}+\mathrm{K}_{2} \mathrm{O}\right)-\mathrm{FeO}$ ternary diagram (Fig. 4) and $\left(\mathrm{Na}_{2} \mathrm{O}+\mathrm{K}_{2} \mathrm{O}\right)-$ $\mathrm{FeO}$ diagram (Fig. 5 ) show the calc-alkaline, respectively subalkaline features of the rhyolites.

3.3. De la Roche diagram (1980) (fide Batchelor and Bowden, 1985)

In this diagram the rhyolites fell in the syn-collision type (Fig. 9). The two samples placed towards the mantle fractionates or to the postorogenic field seem to represent the latest dykes, possibly originated from a deeper source.

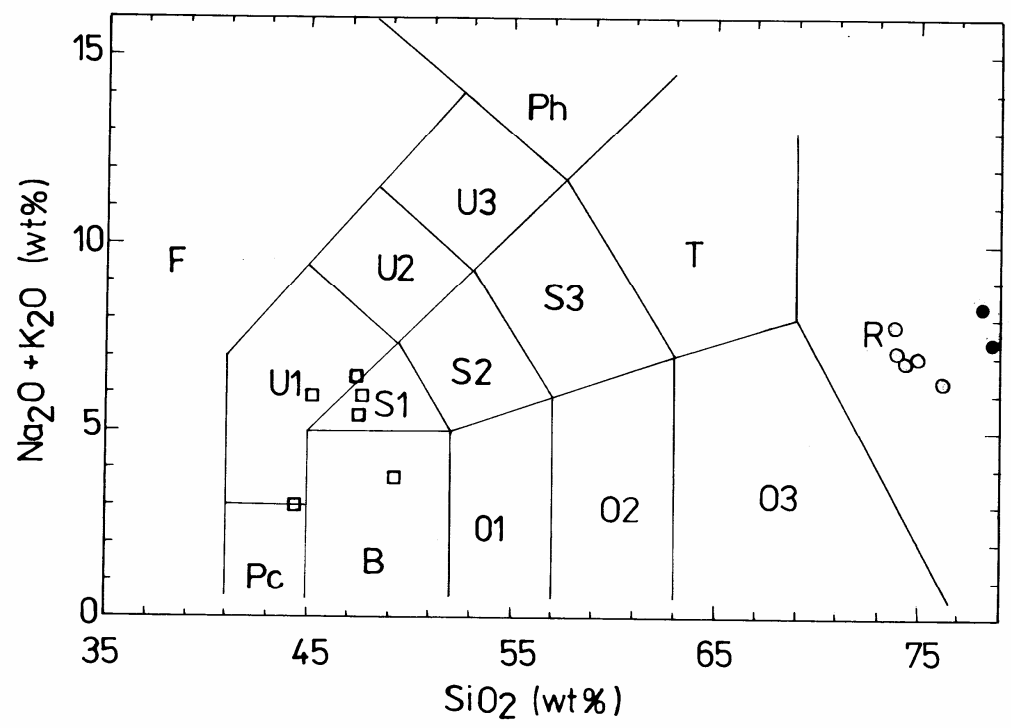

Fig. 10. The TAS classification diagram (acc. to Le Maitre, 1984 diagram) for the Budureasa $(\lambda)$ and Pietroasa $(\mathrm{O})$ rhyolites and Pietroasa ( $\square$ ) basic rocks (free-of-water recalculated values). 


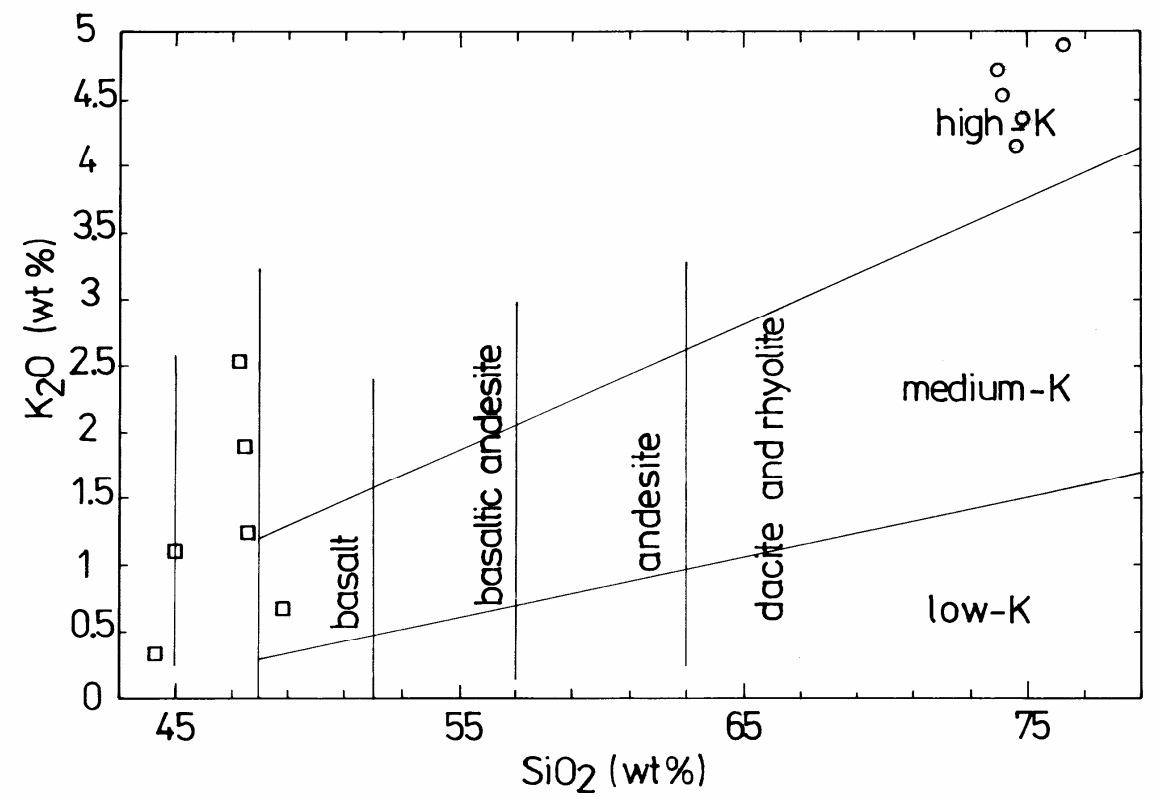

Fig. 11. The alkaline (potassic) tendency (acc. to Le Maitre, 1984 diagram) of the Pietroasa rhyolites (O) and Pietroasa basic rocks ( $\square$ ).

The peralkaline index (P.I.) for rhyolites.

Table 5.

\begin{tabular}{|c|c|c|}
\hline Probe & Area & P.I. \\
\hline 588 & Budureasa & 1.05 \\
\hline 590 & Budureasa & 0.64 \\
\hline 592 & Budureasa & 0.72 \\
\hline 593 & Budureasa & 0.98 \\
\hline 25 & Pietroasa & 0.81 \\
\hline 26 & Pietroasa & 0.75 \\
\hline 52 & Pietroasa & 0.81 \\
\hline 87 & Pietroasa & 0.79 \\
\hline 218 & Pietroasa & 0.63 \\
\hline 517 & Pietroasa & 0.42 \\
\hline
\end{tabular}

\section{DOLERITES AND BASALTS}

Some very small dykes of several meters of dolerites and lamprophyres occur mainly in the Pietroasa area (crossed by drillings and galleries).

The dolerites have a black colour and are relatively fine-crystallized. The textures are ophitic or grainy-ophitic ones, sometimes interrgrainy or intersertale. The plagioclase faldspar (andesine-labradorite), pyroxenes (augite), olivine and opac minerals (magnetite) are the main mineralogical compounds of the dolerites. 
The basalts (Plate I, Fig. 3) present a porphyritic texture with an intersertale groundmass.

For the characterization of the basic rocks occuring at Pietroasa, 6 chemical analyses were used (table 3 ). The acidity ranges from $42.25 \%$ to $45.47 \% \mathrm{SiO}_{2}$. The $\mathrm{Na}_{2} \mathrm{O}$ and $\mathrm{K}_{2} \mathrm{O}$ contents vary between $2.64-4.00 \%$ and $0.30-1.80 \%$ respectively.

\section{1. Irvine and Baragar method (1971)}

The FeO-MgO- $\left(\mathrm{Na}_{2} \mathrm{O}+\mathrm{K}_{2} \mathrm{O}\right)$ diagram places the rocks in a transition field, from calc-alkalin to tholeiitic and confirm their peculiar character (Fig. 4).

The $\mathrm{SiO}_{2}-\left(\mathrm{Na}_{2} \mathrm{O}+\mathrm{K}_{2} \mathrm{O}\right)$ diagram shows the alkaline character of the rocks (Fig. 5), with one exception, which falls at periphery of the subalkalinedomain. The sodic tendency is pointed out by the $\mathrm{Na}_{2} \mathrm{O}-1.5>\mathrm{K}_{2} \mathrm{O}$ relation.

\section{2. T.A.S. diagram (Le Maitre, 1984)}

Because this diagram can be used only for fresh rocks, according to the author's recommendations, the chemical analyses were recalculated free of water (table 6).

Table 6.

Comparison between the average values of some parameters in the volcanic rocks from Budureasa-Pietroasa area and the standard values (Le Maitre, 1984).

\begin{tabular}{|l|c|c|c|c|}
\hline Oxides & $\begin{array}{l}\text { Minimum } \\
\text { value }\end{array}$ & $\begin{array}{c}\text { Maximum } \\
\text { value }\end{array}$ & Average & $\begin{array}{l}\text { Standard } \\
\text { value }\end{array}$ \\
\hline \multicolumn{5}{|c|}{ Rhyolites - Budureasa } \\
\hline $\mathrm{SiO}_{2}$ & 73.26 & 75.00 & 73.76 & 74.26 \\
\hline $\mathrm{CaO}$ & 1.38 & 1.86 & 1.57 & 1.14 \\
\hline $\mathrm{Na}_{2} \mathrm{O}$ & 1.40 & 2.43 & 1.80 & 3.71 \\
\hline $\mathrm{K}_{2} \mathrm{O}$ & 3.85 & 5.78 & 4.76 & 4.26 \\
\hline \multicolumn{5}{|c|}{ Rhyolites - Pietroasa } \\
\hline $\mathrm{SiO}_{2}$ & 67.31 & 72.50 & 68.42 & 74.26 \\
\hline $\mathrm{CaO}$ & 1.56 & 3.00 & 2.45 & 1.14 \\
\hline $\mathrm{Na}_{2} \mathrm{O}$ & 1.75 & 3.07 & 2.30 & 3.71 \\
\hline $\mathrm{K}_{2} \mathrm{O}$ & 2.89 & 4.58 & 3.90 & 4.26 \\
\hline \multicolumn{5}{|c|}{ Basic rocks - Pietroasa } \\
\hline $\mathrm{SiO}_{2}{ }^{*}$ & 36.37 & 42.29 & 40.60 & 44.34 \\
\hline $\mathrm{CaO}^{*}$ & 1.81 & 4.36 & 2.88 & 10.75 \\
\hline $\mathrm{Na}_{2} \mathrm{O}^{*}$ & 2.53 & 3.59 & 3.22 & 3.47 \\
\hline $\mathrm{K}_{2} \mathrm{O}^{*}$ & 0.29 & 2.36 & 1.08 & 1.93 \\
\hline
\end{tabular}

${ }^{*}$ Free of water data. 
In the T.A.S. classification, the Pietroasa basic rocks are placed as follows (Fig. 10 and 11):

- partial within the $U_{1}$ field of the basanites-tefrites (Na-basanites respectively), with a very low $\mathrm{Ca}$ and a high Fe-content;

- partial within the B field, as medium- $\mathrm{K}$ basalts with low $\mathrm{Ca}, \mathrm{Mg}$ and slightly rised Fe contents;

- the majority of the samples join the S1-field; according to Le Maitre (1989), due to the $\mathrm{Na}_{2} \mathrm{O}-2>\mathrm{K}_{2} \mathrm{O}$ values, the basic rocks are of hawaiite type (trachybasalts with sodic tendency).

Comparing the averages of $\mathrm{SiO}_{2}, \mathrm{CaO}, \mathrm{Na}_{2} \mathrm{O}$ and $\mathrm{K}_{2} \mathrm{O}$ from the Budureasa-Pietroasa bodies (table 6 ) with several average values from literature (Le Maitre, 1984), the following can be noticed:

- the $\mathrm{SiO}_{2}$ values for efusive rocks from Budureasa-Pietroasa are smaller than the normal values; the rocks are more basic;

- $\mathrm{Na}_{2} \mathrm{O}$ contents are obviously lower for rhyolites and normal for basic rocks;

- The rhyolites show a slight $\mathrm{CaO}$ enrichment, due to the surrounding limy rocks;

- The $\mathrm{K}_{2} \mathrm{O}$ values for rhyolites are close to the standard values, but the basic rocks show a $\mathrm{K}_{2} \mathrm{O}$ deficit.

\section{THE GEOCHEMISTRY OF TRACE ELEMENTS}

Both the geostructural frame and the parental material magmas were the targets of the geochemical study, based on 4 analysis (table 7 ) of hypabyssal rocks from:

- Budureasa-Sârca Valley: granodiorite (sample 28)

- Budureasa-Mare Valley: granodiorite porphyry (sample 29)

- Pietroasa-Quarry: diorite (xenolith in granodiorite) (sample 31A)

- Pietroasa-Quarry: granodiorite (sample 31B)

The trace-elements and RE contents of the granodiorites and diorite from

Table 7.

Budureasa-Pietroasa area.

\begin{tabular}{|c|c|c|c|c|c|c|c|c|c|c|c|c|c|c|c|}
\hline & $\mathrm{TiO}_{2}$ & $\mathrm{Cu}$ & $\mathrm{Zn}$ & $\mathrm{Ga}$ & $\mathrm{Rb}$ & $\mathrm{Sr}$ & Y & $\mathrm{Zr}$ & $\mathrm{Nb}$ & $\mathrm{Ba}$ & La & $\mathrm{Ce}$ & $\mathrm{Hf}$ & $\mathrm{Pb}$ & Th \\
\hline & $\%$ & \multicolumn{14}{|c|}{$\mathrm{ppm}=\mathrm{mg} / \mathrm{kg}$} \\
\hline $\begin{array}{c}\text { Limit of } \\
\text { detection } \rightarrow\end{array}$ & 0.05 & 5 & 3 & 5 & 2 & 2 & 2 & 2 & 3 & 15 & 15 & 15 & 3 & 3 & 5 \\
\hline $\begin{array}{c}\text { Pr. } 28 \\
\text { Budureasa } \\
\text { granodiorite }\end{array}$ & 0.77 & uld $^{*}$ & 67 & 20 & 38 & 535 & 31 & 712 & 8 & 346 & 18 & 52 & 17 & 49 & uld \\
\hline $\begin{array}{c}\text { Pr. } 29 \\
\text { Budureasa } \\
\text { granodiorite }\end{array}$ & 0.35 & 6 & 41 & 17 & 178 & 133 & 35 & 203 & 11 & 577 & 43 & 78 & 10 & 20 & uld \\
\hline $\operatorname{Pr} 31 \mathrm{~A}$ & 0.89 & 19 & 48 & 21 & 164 & 290 & 37 & 287 & 19 & 567 & 40 & 86 & 10 & 24 & uld \\
\hline
\end{tabular}




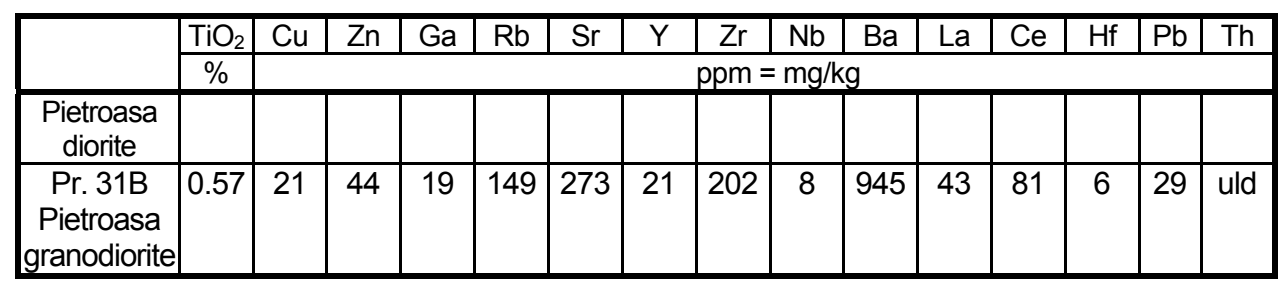

* uld $=$ under limits of detection

Chemical analyses for trace elements (Ti, Cu, Zn, Ga, Rb, Sr, Y, Zr, $\mathrm{Nb}, \mathrm{Ba}, \mathrm{La}, \mathrm{Ce}, \mathrm{Hf}, \mathrm{Pb}$ and Th) were made by ED-XRFA (the X-ray Fluorescence Neutronic Thermic Activation method) ${ }^{5}$.

Two kinds of geochemical patterns were performed: a) the identification of the geostructural conditions of the magma genesis and $b$ ) the normalisations of the trace-element contents to the average content of the continental and oceanic crust.

A) The $\mathrm{Y}+\mathrm{Nb} / \mathrm{Rb}$ ratio of these occurences reveals (Fig. 12) the VAG-Volcanic Arc Granitoid character (Pearce et al., 1984).

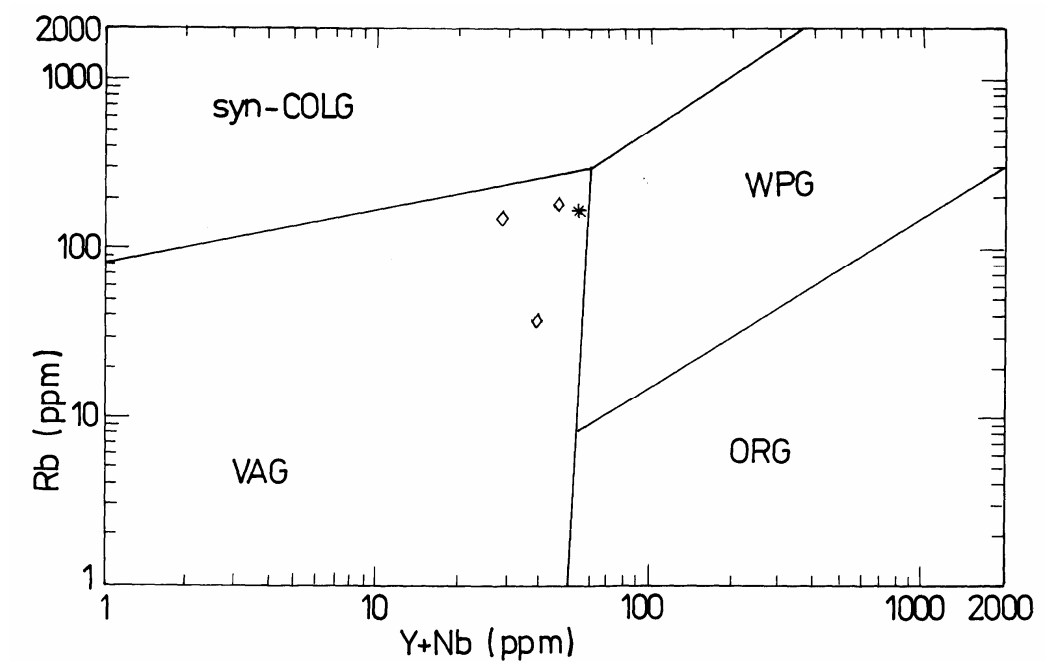

Fig. 12. The $Y+N b / R b$ ratio diagram for some banatites from Budureasa and Pietroasa areas ( $\diamond$ - granodiorite, T - diorite) (according to diagram of Pearce et al., 1973).

B) The second pattern indicates the following conditions:

1. The normalisation granodiorite+diorite/continental crust (Fig. 13) reveals that

\footnotetext{
${ }^{5}$ Analyst: Prof. dr. Doris Stüben (Institut für Petrographie und Geochemie, Karlsruhe University, Germany).
} 
- for most of the elements (Ba, Th, Nb, La, Ce, Sr, Zr, Ti, Y and Zn) the contents are close to those of the continental crust;

- Rb (samples 29, 31A, 31B), Pb and Zn (sample 28) are slightly higher in the granodiorites;

- $\mathrm{Cu}$ is lower in the Budureasa and Pietroasa banatites.

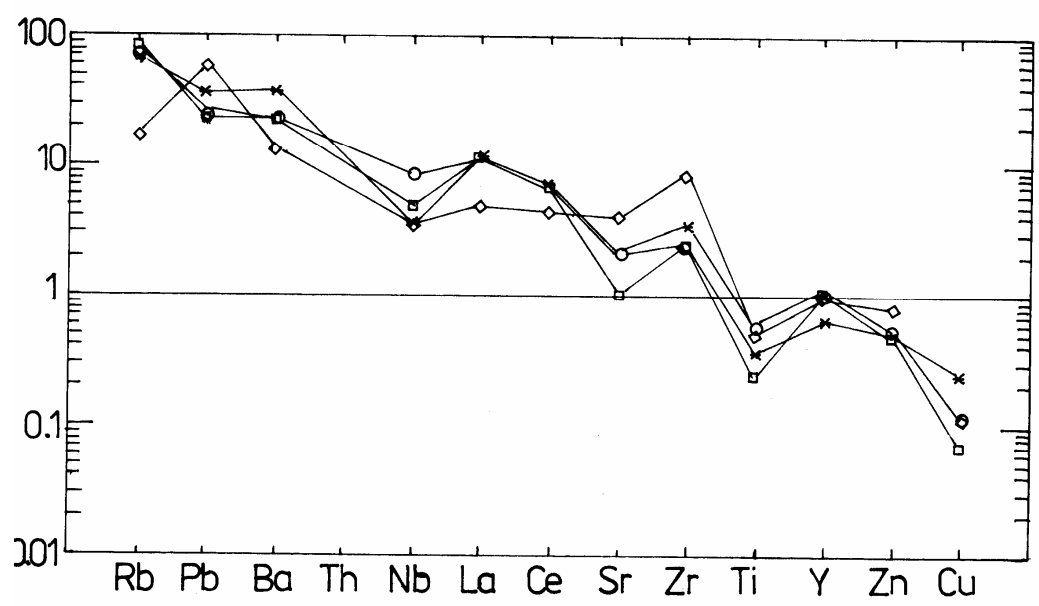

Fig. 13. The normalization banatites/continental crust ( $\mathrm{T}$ - diorite; $\square, \mathrm{O}, \diamond$ - granodiorites)

2. The normalisation granodiorite+diorite/oceanic crust (Fig. 14) exhibits a different distribution of the trace-elements:

- an enrichment of the granodiorites in $\mathrm{Rb}, \mathrm{Pb}, \mathrm{Ba}, \mathrm{Th}, \mathrm{Nb}, \mathrm{La}, \mathrm{Ce}$, $\mathrm{Sr}$ and $\mathrm{Zr}$, in comparison with the oceanic crust;

- very close values for $\mathrm{Sr}, \mathrm{Zr}, \mathrm{Ti}, \mathrm{Y}$ and $\mathrm{Zn}$;

- lower $\mathrm{Cu}$ values in granodiorites than in the oceanic crust.

The $\mathrm{Y}+\mathrm{Nb} / \mathrm{Rb}$ ratio indicates the affiliation of the BudureasaPietroasa rocks to the volcanic (continental) arc granites.

The similarity between the trace-element contents ( $\mathrm{Th}, \mathrm{Nb}, \mathrm{La}, \mathrm{Ce}$, $\mathrm{Sr}, \mathrm{Zr}, \mathrm{Ti}, \mathrm{Y}$ and $\mathrm{Zn}$ ) of the studied rocks and the average content of the continental crust, suggests the partial continental origin of the melted material. It is possible that these elements were partly provided from sediments covering the oceanic plate. The enrichment in $\mathrm{Rb}, \mathrm{Ba}$ and $\mathrm{Pb}$ and the impoverishment in $\mathrm{Cu}$ are due to the magmatic differentiation or postmagmatic metasomatic processes.

The values obtained in this study are close to the values of Ştefan et al. (1992). The $\mathrm{Rb} / \mathrm{Sr}$ ratio (0.071-1.338 for Budureasa granodiorites, 0.546 for Pietroasa granodiorites and 0.565 for Pietroasa diorites) is in general less than 1.0. 


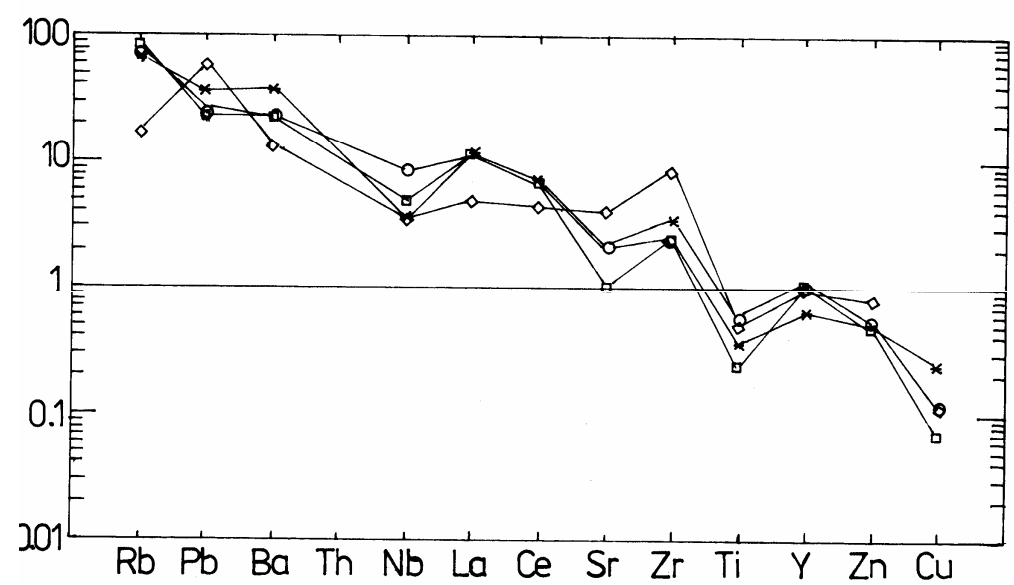

Fig. 14. The normalization banatites/oceanic crust (T - diorite; $\square, \mathrm{O}, \diamond$-granodiorites).

The interpretation of the tectostructural conditions based on the rare-elements content (Pearce et al., 1984) shows the syn-collisional character of the Budureasa and Pietroasa granitoids.

\section{CONCLUSIONS. THE TECTONIC SETTING OF THE BUDUREASA} AND PIETROASA BANATITES

After the opening of the main Tethys (Debelmas and Săndulescu, 1987), and the obduction of an island arc during the contractional period, the subduction continued beneath the Pre-Apulian craton.

The banatites from the North-Western Apuseni Mts. (including Budureasa and Pietroasa intrusive bodies) represent the result of the oceanic crust subduction (Getic plate) in the western basin (Rădulescu, 1974).

The Budureasa and Pietroasa banatite bodies belong to the second stage (Istrate and Udubaşa, 1980; Ştefan et al., 1988), respectively to the third stage (Cioflica et al., 1995) of the Laramian magmatism, which has mainly a calco-alkalin character.

Despite the unitary appearance of the Apuseni Mountains banatitic magmatism, the petrochemical studies reveal some differences between the Budureasa and Pietroasa igneous bodies. Generated in the same structural frame (continental arc granitoids), the Budureasa magmas preceded in time the more alkaline Pietroasa magmas. The petrochemical differences observed between the Budureasa and Pietroasa banatitic bodies are at variance with the presence of a single, deep situated, batholite with large apophyses (as the Budureasa and Pietroasa bodies were considered) ${ }^{6}$. It is possible that these differences are due to the slow evolving of the magma, which allowed the emplacement of the different intrusions, at different

${ }^{6}$ A similar situation was shown by Russo et al. (1978) in the Bocşa banatitic intrusion, where the western part of the pluton has obviously a different character (an alkaline one). 
distances from the subduction front. The magma genesis begun closer to the subduction front (the Budureasa body) and continued further in time with the Pietroasa body ${ }^{7}$. Another hypothesis presumes the presence of two different subduction planes, converging towards the Budureasa and Pietroasa zones, generating similar magmas, but in different tectonic environments.

The magmas which have generated the acide dykes had the same source as the granodiorites and followed a normal differentiation line.

It is thought that the basic rocks from Bihor Mts. do not belong to the same magmatic source as the granodiorites and rhyolites. It is presume that the basic magma sources were deeper placed and the magma has ascended along some crustal fractures, active in the post-orogenic stages. However, the absolute-age studies ${ }^{8}$ showed for some basalts in Bihor Mountains, ages of 75 and $68 \mathrm{Ma}$, and that means they are almost contemporary with the other rocks of Budureasa massif, as monzogranites (88-54.5 Ma), quartziferous diorites (86-65 Ma) and granodiorites (67-57 Ma). Therefore, the rocks from Budureasa area reveal a long-time evolution, emplacement and crystallization of the diorite-granodiorite-granite magmas: from 88 to even 54.5 Ma.

\section{REFERENCES}

1. B a t c h e l or, R. A., B ow d e n, P. (1985) Petrogenetic interpretation of granitoid rock series using multicationic parameters. Chem. Geol., 48, 43-55, Amsterdam.

2. B o r c o ş, M., V I a d, S. (1994) Plate tectonics and metallogeny in the East Carpathians and Apuseni Mts., Field trip guide, Inst. Geol. Rom., 43 p., Bucuresti.

3. C i o fl i c a, G., J u d e, R., L u p u l e s c u, M. (1995) Petrometallogenetic models in the areas with the End Maastrichtian-Paleocene granitoid intrusions of Romania. Studia Univ. Babeş-Bolyai Cluj-Napoca, Geologia, LX, 1, 39-52, Cluj-Napoca.

4. D e L a R o c h e, H., L e te r rie r, J., G r a n d Cl a u d e, P., M a r c h a I, M. (1980) A classification of volcanic and plutonic rocks using R1-R2 diagrams and major element analyses - its relatioship with current nomenclature. Chem. Geol., $29,183-210$.

5. D e b e I m a s, J., S ă n d u I e s c u, M. (1987) Transformante nord-penninique et problemes de correllation palinspastique entre les Alpes et les Carpathes. Bull. Soc. Geol. France, (8), III, 2, 403-408, Paris.

6. Erhan, V., On ice an u, M., Gandrabura, E., C ovali, Gabriela (1980) Date petrochimice asupra magmatitelor laramice din Masivul Budureasa (Munții Apuseni). An Univ. Al.I.Cuza, S.II, b., Geol.-Geogr., XXVI, 5-10, Iaşi.

7. G G u ş c ă, D., C i o f I i c a, G., S a v u, H. (1966) Caracterizarea petrologică a provinciei banatitice. An. Com. Stat Geol., XXXV, 13-45, Bucureşti.

\footnotetext{
${ }^{7}$ Absolute-age studies for both Budureasa and Pietroasa rocks can confirm this hypothesis.

${ }^{8}$ Mânzatu, Silvia, Lemne, Maria, Tănăsescu, Anca, Vâjdea, Eleonora, Romanescu, Olivia. Report, IGG Bucharest Arch., Unpubl. 
8. G i u ş c ă, D., C i o f I i c a, G., S a v u, H. (1965) Les caracteres chimiques des roches de la province banatitique. Asoc. Geol. Carp.-Balk., Congr. VIII, III, Sofia.

9. I o n e s c u, C o r i n a (1997) Studiul metalogenetic al maisvelor banatitice Budureasa şi Pietroasa (Munții Bihor). Teză de doctorat, Univ. Babeş-Bolyai ClujNapoca.

10. I r v i n e, T. N., B a r a g a r, W. R. A. (1971) A guide to the chemical classification of the common volcanic rocks. Canad. Jour. of Earth Sci., 8, 523-548.

11. I s t r a t e, G h., U d u b a ş a, G h. (1980) Contributii la cunoaşterea metalogenezei masivului banatitic Budureasa (Munții Apuseni). D. S. Inst. Geol. Geof., LXV/2, (1977-1978), 5-19, Bucureşti.

12. L e M a i t r e, R. W. (1984) A proposal by the IUGS Subcomission on the systematics of Igneous Rocks for a chemical classification of volcanic rocks based on the total alkali silica TAS) diagram. Austral. Jour. of Earth Sci., 31, 243255.

13. L e M a i t r e, R. W. (Editor) (1989) A Classification of Igneous Rocks and Glossary of Terms. Blackwell Sc. Publ., $128 \mathrm{p}$.

14. M a n i a r, P. D., P i c c o I i, P. M. (1989) Tectonic discrimination of granitoids. Geol. Soc. Amer. Bull., 101, 635-643.

15. M a r i n c e a, Ş t. (1993) Mineralogical data concerning the magnesian hornfels in the Pietroasa area (Bihor Mountains). Rom. J. Mineral., 76, 29-41, Bucureşti.

16. M â r z a, I., I o n e s c u, C o r i n a (1998) Isolithic and heterolithic xenoliths in the Laramian intrusions from Budureasa and Pietroasa, Apuseni Mts., Romania. XVI Congress Carp.-Balk. Geol. Assoc., Abstr. vol., p. 372, Vienna, Austria.

17. P ă t r a ş c u, S t., P a n a i o t u, C., Ş e c I ă m a n, M., P a n a i o t u, C. E. (1994) Timing of rotational motion of Apuseni Mountains (Romania): paleomagnetic data from Tertiary magnetic rocks. Tectonophysics, 233 (1994), 163-176.

18. P e a r c e, J. A., H a r r I s, N. B. W., T i n d I e, A. G. (1984) Trace element discrimination diagrams for the tectonic interpretation of granitic rocks. Journ. Petrol., 25, 956-983.

19. P e c s k a y, Z., E d e Is te in, O., S e ghe di, I., S z a k a c s, A., K o v a c s, M., C r i h a n, M., B e r n a d, A. (1995) K-Ar datings of Neogene-Quaternary calc-alkaline volcanic rocks in Romania. Acta Vulcanol., 7, 2, 53-61.

20. R u s s o, D o in a, B e r z a, T., B r a t o s i n, I r i n a, I a n c, R o s e t t e (1978) Petrological study of the Bocşa Banatitic Massif (Banat). D. S. Inst. Geol. Geofiz., LXIV/1 (1976-1977), 105-172. Bucureşti.

21. R ă d u I e s c u, D. (1974) Observații asupra magmatismului alpin în teritoriile carpatice. D. S. Inst. Geol. Geof., LX/5 (1972-1973), 105-117, Bucureşti.

22. S t o i c o i c i, E., S ă I ă g e a n, I. (1970) Contribuții la cunoaşterea magmatismului banatitic din Munții Bihor. Studia Univ. Babeş-Bolyai Cluj, XV, 2, 3-16, Cluj-Napoca.

23. Ş t e f a n, A., L a z ă r, C., B e r b e l e a c, I., U d u b a ş a, Gh. (1988) Evolution of banatitic magmatism in the Apuseni Mts. and associated metallogenesis. D. S. Inst. Geol. Geof., 72-73 /2 (1985, 1986), 195-213, Bucureşti.

24. Ş tefan, A., Roşu, E., Andăr, A., Robu, Lucia, Robu, Bratosin, Irina, R a b a ri, E., S to i a n, M a ri a, Vâ j d e a, E l e o n or a (1992) Petrological and geochemical features of banatitic magmatites in Northern Apuseni Mountains. Rom. J. Petrol., 75, 97-115, Bucureşti. 


\section{PLATE I.}

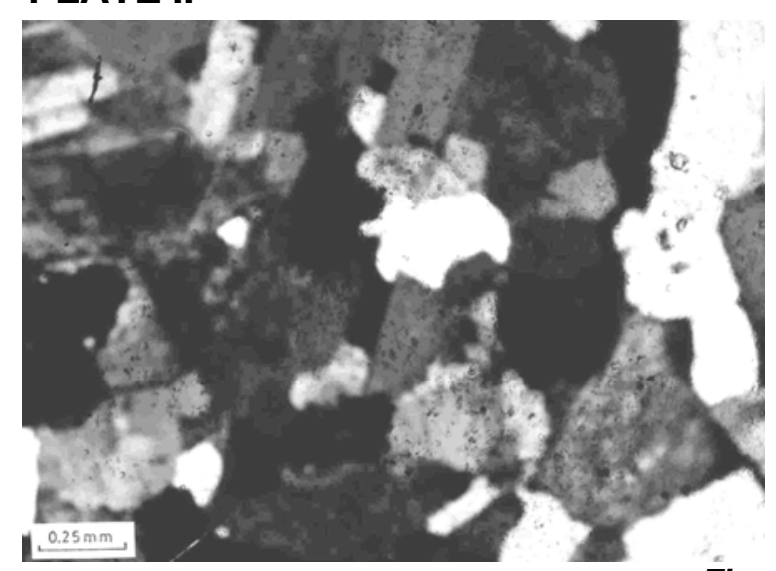

Fig. 1. Granodiorite from Budureasa. N+.
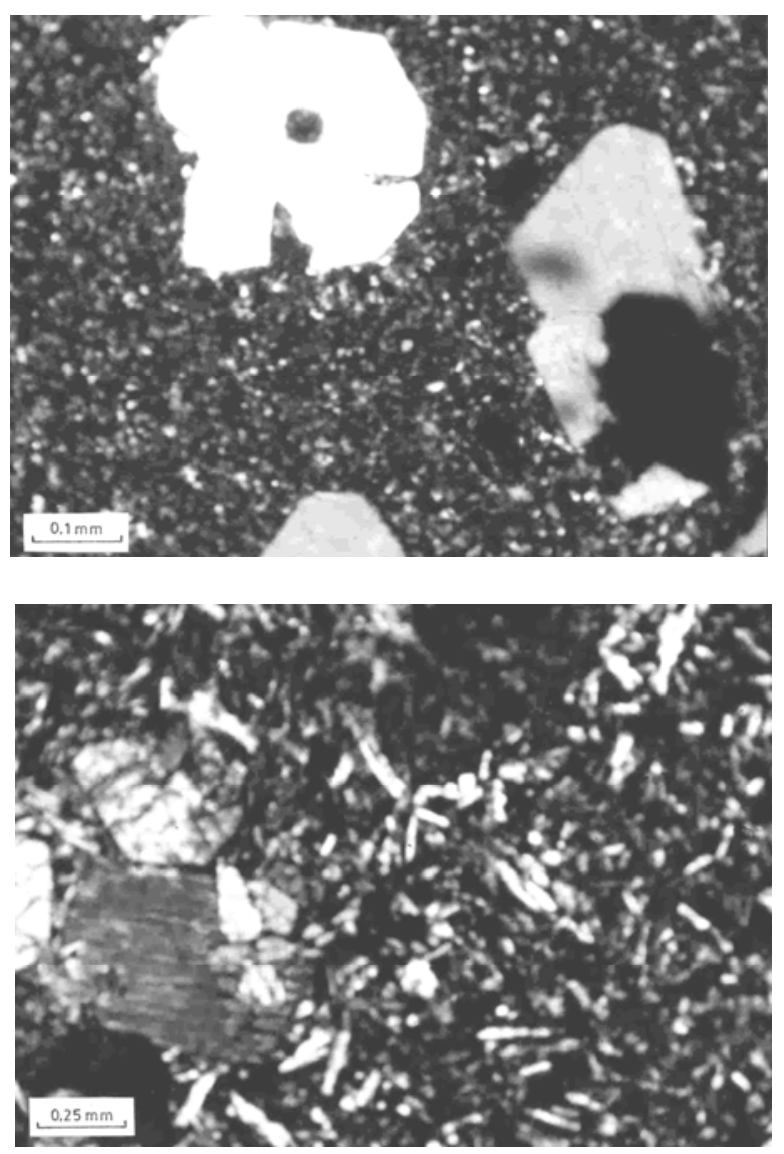

Fig. 2. Rhyolite. Budureasa. N+

Fig. 3. Basalt. Pietroasa. $\mathrm{N}+$. 